\title{
BAGAIMANA PERAWATAN KESEHATAN DAN DUKUNGAN KELUARGA DENGAN IBU HAMIL BERPERAN DALAM PEMANFAATAN PELAYANAN KESEHATAN VCT
}

\section{HOW HEALTH CARE AND FAMILY SUPPORT WITH PREGNANT WOMEN PLAY A ROLE ON UTILIZATION OF VCT HEALTH SERVICES}

\author{
Ni Putu Wiwik Oktaviani ${ }^{1}$, Ni Luh Putu Devhy ${ }^{3}$, I Made Sudarma Adiputra, \\ Dewa Ayu Putri Widiastuti2. \\ STIKes Wira Medika Bali ${ }^{123}$
}

\begin{abstract}
ABSTRAK
Pendahuluan: AIDS adalah penyakit yang disebabkan oleh infeksi dengan virus yang disebut Human Immunodeficiency Virus (HIV), yang dimana kasus HIV pada ibu rumah tangga menduduki peringkat kedua. Penularan melalui perinatal menyumbang 5,1\%. Penularan tersebut dapat dicegah jika ibu hamil sejak dini diketahui statusnya dan mendapat pengobatan dengan tepat. Integrasi program pencegahan HIV dari ibu kebayi pada pelayanan antenatal care telah dilakukan, namun keikutsertaaan ibu hamil untuk VCT masih rendah. Dukungan keluarga sangat penting dalam mendukung keikutsertaaan ibu hamil untuk VCT. Tujuan dari penelitian ini adalah untuk mengetahui gambaran fungsi perawatan kesehatan dan dukungan keluarga dengan ibu hamil dalam pemanfaatan pelayanan kesehatan VCT. Metode: Desain penelitian ini merupakan penelitian deskriptif dengan rancangan cross sectional. Studi dilakukan di Puskesmas I Susut, Bangli dengan jumlah sampel sebanyak 93 reponden dengan teknik non-probabiliti sampling dengan purposive sampling. Data yang diperoleh dianalisis dengan program komputerisasi dengan menggunakan analisis univariat. Hasil: Hasil menunjukan sebagian besar responden memiliki fungsi perawatan kesehatan tidak efektif 54,8\% dan sebagian besar responden memiliki dukungan keluarga cukup 46,2\%. Diskusi: Hasil penelitian ini dapat direkomendasikan diterapkan pada keluarga melalui peran kader kesehatan dan pihak puskesmas untuk meningkatkan kembali pelayanan kesehatan VCT terhadap Ibu hamil.
\end{abstract}

Kata Kunci : Perawatan Kesehatan, Dukungan Keluarga, Ibu Hamil

\section{ABSTRACT}

Introduction: AIDS is a disease caused by infection with a virus called Human Immunodeficiency Virus (HIV), and the number of women who infected with HIV has increased year by year. Through perinatal transmission contributed $5.1 \%$. The transmission can be prevented if pregnant woman know their status and get treatment appropriately. Integration of maternal to infant HIV prevention programs on antenatal care hip services is done, but the participation of pregnant women for VCT is still low. The family supports are important to support adherence participation of pregnant women for VCT. Method: This research aimed to description of the function health care and family support with pregnant woman on 
utilization of VCT health services. This study of description with cross sectional design. Study was conducted at Puskesmas I Susut Bangli with 93 samples was taken by non-probability sampling with purposive sampling. Obtained data was processing SPSS and analyzing by univariate test. Result: Research of study showard most respondents have a not effective Function health care 54,8\% and most respondents have a enough family support 46,2\%. Discussion: The results of this study research can be recommended to be applied to the family and the health community center or clinics to improve again the health services VCT to wards pregnant women.

Keyword : Health care, Family support, Pregnant women

Alamat Koresponden : Br. Manukaya Let, Tampaksiring, Gianyar, Bali.

Email : putriayudewa7@gmail.com

\section{PENDAHULUAN}

Penyakit Human Immunodeficienty Virus (HIV) merupakan salah satu masalah kesehatan yang masih menjadi permasalahan di dunia saat ini. Jumlah kasus HIV/AIDS mengalami penurunan pada tahun 2016, tetapi angka kejadian telah dilakukan untuk menekan jumlah penularan virus HIV ini. Salah satunya tercantum dalam Sustainbale Development Goals (SDGs) 3.3, yaitu menghentikan epidemi AIDS, tuberculosis, malaria, neglected tropical disease, pemberantasan hepatitis, penyakit yang ditularkan melalui air dan penyakit menular lainnya (Kementrian Kesehatan RI, 2016).

Prevalensi dan penularan HIV dari ibu ke bayi masih terbatas, jumlah ibu hamil yang terinfeksi HIV cenderung meningkat. Prevalensi HIV pada ibu hamil diproyeksikan meningkat dari 0,38\% tahun 2012 menjadi 0,49\% pada tahun 2016 . Lebih dari 90\% kasus anak yang terinfeksi HIV, ditularkan melalui proses penularan dari ibu ke anak atau mother to child HIV transmission (MTCT) (Kemenkes, 2012). Virus HIV dapat ditularkan dari ibu yang terinfeksi HIV kepada anaknya selama kehamilan saat persalinan dan menyusui. Risiko penularan HIV dari ibu ke anak tersebut diperkirakan 5-10\% selama kehamilan, 10-20\% selama persalinan dan 5-20\% selama menyusui. Rendahnya pengetahuan dan informasi tentang penularan dari ibu ke anak menunjukkan bahwa persentase penduduk yang mengetahui bahwa HIV-AIDS dapat ditularkan dari ibu ke anak selama hamil, saat persalinan, dan saat menyusui adalah masing-masing 38,1\%, 39,0\%, dan 37,4\% (Kementrian Kesehatan Republik Indonesia, 2013).

Data dari Komisi Penanggulangan AIDS (KPA) Bali 2012 menyatakan bahwa berdasarkan perhitungan, menunjukan bahwa sekitar 500 ibu hamil di Bali diperkirakan positif HIV/AIDS setiap tahun. Pola penularan HIV pada ibu hamil tersebut, adalah penularan dari suami yang berganti-ganti pasangan seksual kepada istrinya. Penularan tersebut tidak hanya pada ibu hamil yang terinfeksi HIV dari suami saja, namun berlanjut kepada anak yang dikandungnya (Komisi Penanggulangan AIDS Provinsi Bali, 2012)

Di Provinsi Bali kasus kumulatif HIV/AID sejak di temukan di Bali tahun 1987 sampai dengan bulan Desember 2014 adalah sebesar 10.675 orang (Dinkes 
Provinsi Bali, 2015). Pada tahun 2015 jumlah ibu hamil yang sudah melakukan tes HIV di bali sebanyak 20.610 orang atau $29 \%$ dari sasaran ibu hamil sebanyak 70.095 orang. Ibu hamil yang melakukan tes HIV tersebut 105 orang dinyatakan positif HIV, dari semua kabupaten di Bali, kasus terbanyak ditemukan di kota Denpasar kemudian Buleleng dan Badung. Jumlah kumulatif kasus HIV/AIDS sejak ditemukan tahun 1987 sampai dengan tahun 2015 di kota Denpasar sebanyak 4974 kasus (Dinkes Provinsi Bali, 2015).

Upaya pemerintah saat ini untuk mencegah terjadinya penularan HIV dari ibu ke anak, dilaksanakan program pencegahan secara komprehensif meliputi empat strategi yaitu pencegahan penularan HIV pada perempuan usia reproduksi, pencegahan kehamilan yang tidak direncanakan pada perempuan HIV positif, pencegahan penularan HIV dari ibu hamil HIV positif ke bayi yang dikandungnya dengan cara melakukan tes Volontary Conseling and Testing (VCT) (Kemenkes RI, 2012).

Selama ini program pemeriksaan VCT belum optimal, masih didominasi oleh kelompok populasi kunci, terdiri dari wanita pekerja seks (WPS) yang sebelumnya telah melakukan metadon. Artinya, pelayanan tes VCT hanya dilakukan oleh sejumlah kecil kelompok, belum secara umum dimanfaatkan oleh masyrakat luas. Dari data seluruh kabupaten di Bali bahwa program pemerintah pada tahun 2017 jumlah ibu hamil yang sudah melakukan tes HIV di Bali sebanyak 52,465 orang atau $85,95 \%$ dari sasaran ibu hamil sebanyak 61,043 orang atau 86,05 $\%$. Ibu hamil yang melakukan tes HIV tersebut 160 orang dinyatakan positif HIV. Di kabupaten Jembrana jumlah ibu hamil yang sudah di tes HIV 4362 orang atau $86,69 \%$, Klungkung 2681 orang dan yang paling terendah terdapat di kabupaten Bangli 2458 orang (Dinkes Provinsi Bali, 2017).

Ibu hamil juga membutuhkan dukungan psikologis dan sosial dari orangorang di sekitar terutama keluarga dan lingkungan sekitar termasuk petugas kesehatan dalam melakukan pencegahan penularan HIV/AIDS dari ibu ke anak. Konseling dalam VCT adalah kegiatan konseling yang menyediakan dukungan psikologis, informasi dan pengetahuan HIV/AIDS, mencegah penularan HIV, mempromosikan perubahan perilaku yang bertanggung jawab, pengobatan antiretroviral (ARV) dan memastikan pemecahan berbagai masalah terkait dengan HIV/AIDS yang bertujuan untuk perubahan perilaku ke arah perilaku lebih sehat dan lebih aman (Depkes RI, 2008). Selain upaya medis, Ibu HIV membutuhkan dukungan psikologis dan sosial dari orang-orang di sekitar terutama keluarga.

Peran Keluarga Sangat dibutuhkan khususnya dalam memberikan perawatan, tidak hanya perawatan secara fisik akan tetapi juga perawatan secara psikologis. Kondisi ini menunjukan bahwa setiap keluarga dituntut untuk melakukan fungsinya guna meningkatkan status kesehatan keluarga (Suprajitno, 2007). Fungsi dasar keluarga meliputi fungsi keluarga memberikan kenyamanan emosional, mendidik, mengajarkan nilai, sikap, kepercayaan, membantu memecahkan masalah, meneruskan keturunan, memenuhi kebutuhan material, serta memberikan perawatan kesehatan untuk anggota keluarganya (Susanto, 2012). Salah satu fungsi keluarga yang berperan penting dalam meningkatkan status kesehatan keluarga adalah fungsi perawatan kesehatan keluarga.

Kementrian Kesehatan Republik Indonesia (2012), menjelaskan masih banyak keluarga di Indonesia yang belum melaksanakan fungsi perawatan kesehatan dengan baik dan perlahan-lahan telah terjadi penurunan pelaksanaan 
fungsi keluarga. Hal tersebut dapat dilihat dari prevalensi HIV pada Ibu hamil meningkat dari 0,38\% tahun 2012 menjadi 0,49\% pada tahun 2016 (Kemenkes, 2012). Fungsi perawatan kesehatan keluarga tidak hanya bermitra pada keluarga dank klien, tetapi peran perawat juga sangat dibutuhkan dalam keluarga untuk mengarahkan dan mengimplementasikan perawatan kesehatan (Potter \& Perry, 2009). Peran penting perawat keluarga adalah bekerja dengan keluarga untuk merencanakan modifikasi gaya hidup sehingga tujuan kesehatan dapat tercapai. Peningkatan kesehatan dalam keluarga merupakan tujuan dasar dari keperawatan keluarga untuk mendapatkan informasi tentang kesehatan keluarga guna membantu keluarga dalam meningkatkan kesehatan keluarga. (Friedman, Bowden \& Jones, 2010).

Berdasarkan studi pendahuluan yang dilakukan di Puskesmas 1 susut Bangli, di dapatkan jumlah ibu hamil tahun 2018 tercatat 120 orang dari hasil wawancara dengan bidan di poli klinik kebidanan dan kandungan Puskesmas 1 susut bangli masih ada beberapa ibu yang menolak melakukan pemeriksaan VCT. Hal ini dipengaruhi oleh pengetahuan rendah ibu hamil dan kurangnya dukungan dari keluarga.

Berdasarkan fenomena dan data yang telah diuraikan tersebut menjadikan dasar bagi peneliti untuk mengetahui fungsi perawatan kesehatan dan dukungan keluarga dengan ibu hamil dalam pemanfaatan pelayanan kesehatan VCT.

\section{BAHAN DAN METODE}

Rancangan penelitian yang digunakan dalam penelitian ini adalah deskriptif. Desain ini menggunakan pendekatan cross-sectional design. Penelitian ini dilakukan di wilayah kerja Puskesmas 1 Susut Bangli yang dilaksanakan pada bulan Juni 2017. Sampel penelitian ini dipilih sebanyak 93 orang responden mengunakan teknik sampling non probability sampling dengan purposive sampling berdasarkan kriteria inklusi dan eksklusi yang sudah ditentukan. Instrument yang digunakan dalam penelitian ini yaitu kuisioner dukungan keluarga dan fungsi perawatan kesehatan diukur yang sebelumnya telah dilakukan uji validitas dan reabilitas. Data dianalisis mengunakan uji univariat.

\section{HASIL}

1. Analisa yang dilakukan memperoleh hasil sebagai berikut:

Tabel 1 Distribusi Frekuensi Responden Berdasarkan Karakteristik Responden di Wilayah kerja Puskesmas 1 Susut Bangli

\begin{tabular}{ccc}
\hline Umur & F & \% \\
\hline \multirow{2}{*}{$\mathbf{1 7 - 2 5}$} & 16 & $\begin{array}{c}17, \\
2\end{array}$ \\
\hline \multirow{2}{*}{$\mathbf{2 6 - 3 5}$} & 46 & $\begin{array}{c}49, \\
5\end{array}$ \\
\hline \multirow{2}{*}{$\mathbf{3 6 - 4 5}$} & 31 & 33, \\
& & 3 \\
\hline Total & 93 & 100 \\
\hline gft & $\mathbf{F}$ & $\%$ \\
\hline
\end{tabular}




\begin{tabular}{ccc}
\hline Tidak Sekolah & 5 & 5,4 \\
\hline SD & 13 & $\begin{array}{c}14, \\
0\end{array}$ \\
\hline SMP & 27 & $\begin{array}{c}29, \\
0\end{array}$ \\
\hline SMA & 43 & $\begin{array}{c}46, \\
2\end{array}$ \\
\hline Perguruan Tinggi & 5 & 5,4 \\
\hline Total & 93 & 100 \\
\hline Pekerjaan & F & $\mathbf{\%}$ \\
\hline PNS & 3 & 3,2 \\
\hline Swasta & 17 & $\begin{array}{c}18, \\
3\end{array}$ \\
\hline Wiraswasta & 18 & $\begin{array}{c}19, \\
4\end{array}$ \\
\hline Petani & 37 & $\begin{array}{c}39, \\
8\end{array}$ \\
\hline Tidak Bekerja & 18 & $\begin{array}{c}19, \\
4\end{array}$ \\
\hline Total & 93 & 100 \\
\hline
\end{tabular}

Tabel 2 Fungsi Perawatan Kesehatan DalamPemanfaatan Pelayanan Kesehatan VCT

\begin{tabular}{ccc}
\hline Fungsi Perawatan Kesehatan & F & \% \\
\hline Efektif & 42 & 45,2 \\
\hline Tidak Efektif & 51 & 54,8 \\
\hline Total & 93 & 100 \\
\hline
\end{tabular}

Tabel 3 Dukungan Keluarga Dengan Ibu Hamil Dalam Pemanfaatan Pelayanan Kesehatan VCT

\begin{tabular}{ccc}
\hline Dukungan Keluarga & F & \% \\
\hline Baik & 30 & 32,3 \\
\hline Cukup & 43 & 46,2 \\
\hline Kurang & 20 & 21,5 \\
\hline Total & 93 & 100 \\
\hline
\end{tabular}

\section{PEMBAHASAN}

Karakteristik Responden Dalam Pemanfaatan Pelayanan Kesehatan VCT

Berdasarkan umur mayoritas responden berada pada kelompok usia 26-35 tahun sebesar 49,5\% dan termasuk ke dalam kategori dewasa awal. Responden pada penelitian ini menggambarkan mayoritas berada pada usia produktif serta tidak ada hambatan dalam segi fisik untuk melakukan konseling VCT. Menurut pendapat Andersen (2007) umur merupakan satu faktor yang mempengaruhi dalam pemanfaatan pelayanan kesehatan. Menurut Effendy (2010) semakin cukup umur tingkat kematangan dan kekuatan seseorang, maka akan lebih matang sesorang 
tersebut dalam berfikir dan berkarya. Hasil penelitian ini sejalan dengan penelitian Montolulu (2014), penelitian tersebut mendapatkan mayoritas ibu hamil yang melakukan pelayanan VCT berada pada usia produktif 20-35 tahun sebesar 83,5\% di Puskesmas Bahu Kota Manado. Menurut peneliti mayoritas ibu hamil berada pada usia produktif sehingga ibu hamil diharapkan tidak mempunyai keterbatasan dalam segi fisik dalam pemanfaatan pelayanan kesehatan VCT.

Berdasarkan pendidikan didapatkan sebagian besar responden memiliki tingkat pendidikan SMA yaitu sebanyak 46,2\% (43 orang responden). Hasil tersebut menunjukan pendidikan akan mempengaruhi dukungan keluarga yang diberikan serta fungsi perawatan kesehatan ibu hamil. Pendidikan seseorang sangat erat berhubungan dengan pengatahuan yang akan membentuk sikap dan dapat mempengaruhi prilaku seseorang. Semakin tinggi pengetahuan seseorang diharapkan akan mampu membentuk prilaku seseorang sesuai dengan norma dan nilai yang baik dan berorientasi pada hal yang benar (Notoatmojo, 2012). Hasil penelitian ini sejalan dengan penelitian yang dilakukan oleh Pradnya (2016), dalam penelitiannya didapatkan sebagian besar responden memiliki tingkat pendidikan SMA yaitu sebanyak 45,7\% (32 orang responden) di Poliklinik VCT (Voluntary Counseling and Test) BRSU Tabanan. Menurut peneliti masih banyaknya ditemukan ibu hamil yang memiliki pengetahuan rendah yang tidak melakukan pemeriksaan VCT karena seseorang keliru tentang pentingnya melakukan pemeriksaan VCT selama kehamilan.

Berdasarkan pekerjaan sebagian besar responden berprofesi sebagai petani yaitu sebanyak 39,8\% (37 orang responden). Pekerjaan secara tidak langsung akan mempengaruhi dukungan keluarga salah satunya dukungan instrumental. Pekerjaan memiliki peran yang sangat besar dalam memenuhi kebutuhan hidup manusia, terutama kebutuhan ekonomis, sosial dan psikologis (Embi, 2008).Pengalaman dalam bekerja yang berkembang memberikan pengetahuan dan keterampilan professional serta pengalaman belajar selama bekerja akan dapat mengembangkan kemampuan dalam mengambil keputusan. Hasil penelitian ini sejalan dengan penelitian yang dilakukan oleh Iswandari dan Ramayani (2012) menunjukkan bahwa sebagian besar responden berprofesi sebagai petani yaitu sebanyak $42,0 \%$ dan diurutan kedua berprofesi sebagai buruh yaitu sebesar 38,1\%. Menurut pendapat peneliti hal ini dikarenakan di Wilayah kerja Puskesmas I Susut Bangli terdapat banyak persawahan, baik itu milik Ibu sendiri maupun Ibu bekerja sebagai buruh tani untuk sawah orang lain. Hasil wawancara yang peneliti lakukan, Ibu mengatakan kurang mengetahui informasi tentang manfaat pemeriksaan kesehatan VCT, karena Ibu harus bekerja dari pagi sampai sore di sawah. Dapat dilihat berdasarkan hasil penelitian bekerja bukan berarti jadi penghalang buat para ibu tidak patuh dalam pemeriksaan VCT.

\section{Dukungan Keluarga Dengan Ibu Hamil Dalam Pemanfaatan Pelayanan Kesehatan VCT}

Penelitian ini mengidentifikasi dukungan keluarga dengan ibu hamil dalam pemanfaatan pelayanan kesehatan VCT di wilayah kerja Puskesmas I Susut Bangli hasil didapatkan dari keseluruhan responden sebagian besar responden memiliki dukungan keluarga yang cukup yaitu sebanyak 46,2\% (43 orang responden). Keluarga memiliki fungsi salah satunya adalah fungsi perawatan kesehatan keluarga dalam hal ini keluarga dalam melindungi keamanan dan kesehatan seluruh 
anggota keluarga serta menjamin pemenuhan kebutuhan perkembangan fisik, mental dan spiritual, dengan cara memelihara dan merawat anggota keluarga serta mengenali kondisi sakit tiap anggota keluarga (Achjar, 2010). Menurut Friedman (2010) dukungan keluarga adalah sebuah proses yang terjadi sepanjang masa kehidupan, sifat dan jenis dukungan berbeda dalam berbagai tahap-tahap siklus kehidupan.

Dukungan keluarga dapat berupa dukungan sosial internal, seperti dukungan dari suami, istri atau dukungan dari saudara kandung dan dapat juga berupa dukungan keluarga eksternal bagi keluarga inti. Dukungan keluarga membuat keluarga mampu berfungsi dengan berbagai kepandaian dan akal. Sebagai akibatnya, hal ini meningkatkan kesehatan dan adaptasi keluarga. Dukungan keluarga sangat bermanfaat baik dari segi fisik maupun mental bagi ibu hamil sehingga mengurangi rasa dampak kecemasan, depresi, dan pemikiran negatif tentang pelayanan kesehatan VCT yang dijalaninya dan juga harus adanya keterbukaan responden dengan keluarga agar keluarga mengerti kebutuhan responden begitupun juga sebaliknya (Padila 2013).

Penelitian ini sejalan dengan penelitian yang dilakukan Isni (2016) tentang dukungan keluarga, dukungan petugas kesehatan, dan perilaku ibu HIV dalam pencegahan penularan HIV/AIDS didapatkan sebagian besar keluarga cukup mendukung yaitu sebesar 45,6\%. Sejalan juga dengan penelitian Pradnya (2016) juga mengungkapkan didapatkan responden memiliki dukungan dengan rata-rata skor dukungan keluarga 41,51 (Cukup). Penelitian yang dilakukan oleh Mahardining, A. B. (2010), tentang motivasi dan dukungan keluarga dengan kepatuhan terapi hasil penelitian tersebut menunjukan sebagian besar keluarga memberikan dukungan yang cukup yaitu sebanyak 45,7\% (16 orang responden).

Berdasarkan jurnal internasional didapatkan hasil penelitian ini sejalan dengan penelitian yang dilakukan oleh Abebaw Dimissie (2009) yang berjudul Determinants Of Acceptance Of Voluntary HIV Testing Among Antenatal Clinic Attendees At Dil Chora Hospital, Dire Dawa, East Ethiopia yang menyatakan bahwa ada hubungan yang signifikan antara dukungan suami dengan status pemeriksaan VCT pada ibu hamil. Berdasarkan hasil penelitian dan beberapa data tersebut dukungan keluarga sangatlah penting bagi ibu hamil dalam pemanfaat pelayanan VCT.

Menurut peneliti dukungan keluarga sangat diperlukan dalam keberhasilan pemanfaatan pelayanan kesehatan VCT bagi ibu hamil, hal tersebut disebabkan oleh keluarga merupakan orang terdekat yang selalu dapat memantau dan mengawasi ibu terutama dalam hal memberikan semangat dan motivasi selama menjalani masa kehamilan. Berdasarkan dukungan emosional didapatkan sebanyak $45,2 \%$ keluarga menujukan wajah yang menyenangkan saat ibu pulang dari melakukan pemeriksaan VCT, berdasarkan dukungan informasi didapatkan sebanyak 36,6\% keluarga menasehati ibu untuk mengikuti pelayanaan kesehatan VCT, berdasarkan dukungan instrumental sebanyak 39,8\% keluarga selalu mengantar Ibu untuk melakukan pemeriksan VCT dan berdasarkan dukungan penghargaan sebanyak 34,4\% keluarga memberikan pujian kepada ibu sepulang melakukan pemeriksaan VCT. Tetapi masih banyak ditemukan ibu hamil yang tidak mendapatkan dukungan keluarga disebabkan oleh kurangnya pemahaman keluarga tentang manfaat dan pentingnya melakukan pemeriksaan VCT baik bagi suami dan bagi ibu hamil. Berdasarkan data yang didapatkan di Puskesmas I Susut 
Bangli dari 120 orang ibu hamil hanya sebanyak 63 ibu saja yang sudah melakukan pemeriksaan VCT atau hanya sebesar $52,5 \%$ dan belum mencapai target yang ditentukan sebesar 90,0\%. Selain itu kurangnya dukungan keluarga juga disebabkan oleh tingkat pekerjaan keluarga yang menyebabkan kurangnya waktu untuk memberikan dorongan pada ibu hamil atau menemani ibu hamil ke tempat pelayanan kesehatan.

\section{Fungsi Perawatan Kesehatan Ibu Hamil Dalam Pemanfaatan Pelayanan Kesehatan VCT}

Penelitian ini mengidentifikasi fungsi perawatan kesehatan dengan ibu hamil dalam pemanfaatan pelayanan kesehatan VCT di wilayah kerja Puskesmas I Susut Bangli berdasarkan hasil penelitian didapatkan dari keseluruhan responden sebagian besar responden tidak efektif dalam melakukan fungsi perawatan kesehatan yaitu sebanyak 54,8\% (51 orang responden). Fungsi perawatan kesehatan menjelaskan sejauh mana ibu menyediakan makan, pakaian, perlindungan serta merawat anggota keluarga yang sakit. Sejauh mana pengetahuan ibu meneganal tentang konsep sehat sehat sakit. Harmoko (2012) menjelaskan salah satu fungsi perawatan kesehatan adalah menggunakan fasilitas kesehatan/memanfaatkan pelyanan kesehatan yang ada di masyarakat, apabila mengalami gangguan atau masalah yang berkaitan dengan kesehatan keluarga atau anggota keluarga harus dapat memanfaatkan fasilitas kesehatan yang ada di sekitarnya.

Ibu hamil memiliki berbagai masalah yang komplek terkait dengan kesehatan salah satunya bagaimana cara ibu mengetahui status penyakit di dalam tubuhnya. Merencanakan kehamilan ibu perlu melakukan beberapa screening kesehatan, salah satu yang waji merupakan screening HIV/AIDS pada ibu hamil guna mencegah penularan virus HIV pada bayi. Penegakkan status HIV pada ibu hamil sedini mungkin sangat penting untuk mencegah penularan HIV kepada bayi, karena ibu dapat segera memperoleh pengobatan ARV, dukungan psikologis, dan informasi tentang HIV/AIDS (Kemenkes RI, 2011).

Hasil penelitian ini sejalan dengan penelitian yang dilakukan oleh Bachrum (2017), hasil penelitian tersebut didaptkan sebagian besar responden tidak patuh dalam menjalani terapi ARV yaitu sebanyak 52,0\% (26 orang responden) yang dilakukan di komunitas ODHA. Sejalan dengan penelitian yang dilakukan oleh Novita (2017), hasil penelitian tersebut menyatakan mayoritas responden tidak efektif dalam menciptakan lingkungan yang menunjang kesehatan yaitu sebesar 54,8\% (51 orang). Hasil ini sesuai juga dengan penelitian Mujib (2013) yang menyatakan peran keluarga dalam perawatan anggota keluarga yang sakit terdapat pada kategori cukup yaitu 16 orang (40\%). Sejalan juga dengan penelitian Agnes (2014), tentang pelaksanan pelayanan antenatal dengan keikutsertaan ibu hamil untuk konseling dan tes HIV dalam kategori cukup yaitu $(82,6 \%)$

Menurut peneliti responden yang memiliki fungsi perawatan kesehatan dan pendidikan kesehatan yang kurang baik tidak melakukan pemanfaatan pelayanan kesehatan VCT secara efektif, pada saat wawancara responden mengatakan bahwa responden cukup mendapatkan konseling maupun penyuluhan yang diberikan petugas kesehatan kepada ibu hamil tentang pentingnya pemeriksaan VCT, namun petugas kesehatan tidak pernah memberikan brosur kepada ibu hamil sehingga ibu hamil kurang termotivasi untuk melakukan pemeriksaan VCT. Responden yang melakukan pemeriksaan VCT sangat dipengaruhi oleh peran dan dukungan dari 
keluarga. Sosialisasi pemeriksaan VCT pada ibu hamil dan keluarga sangat penting, mengingat keluarga sangat dekat dengan ibu hamil. Ibu hamil akan melakukan tes VCT karena anjuran dari anggota keluarganya, khsusnya para suami. Hasil kuesioner menunjukan sebanyak 46,2\% keluarga tidak mengetahui perawatan yang tepat/dibutuhkan ibu hamil, sebanyak 47,3\% keluarga tidak mengetahui memberi kasih sayang yang lebih merupakan perawatan sederhana bagi ibu hamil hal tersebut menunjukan alasan sebagian besar ibu tidak efektif dalam melakukan fungsi perawatan kesehatan

\section{SIMPULAN}

\section{SIMPULAN DAN SARAN}

Selama ini program pemeriksaan VCT masih belum optimal, pelayanan tes VCT hanya dilakukan oleh sejumlah kelompok kecil, belum dimanfaatkan oleh masyarakat luas. Berdasarkan hasil penelitian di wilayah kerja Puskesmas I Susut Bangli didapatkan hasil bahwa mengidentifikasi fungsi perawatan kesehatan dan dukungan keluarga dengan ibu hamil dalam pemanfaatan pelayanan kesehatan VCT sebagian besar ibu mendapat dukungan keluarga cukup yaitu sebesar $46,2 \%$ dan sebagian besar ibu memiliki fungsi perawatan kesehatan yang tidak efektif yaitu sebanyak $54,8 \%$.

\section{SARAN}

Masih diperlukan penelitian lebih lanjut tentang dukungan keluarga sebagai salah satu upaya dalam peningkatan pemanfaatan pelayanan VCT mengingat pentingnya fungsi perawatan kesehatan pada ibu hamil serta peningkatan pelayanan oleh profesi keperawatan terkait hasil penelitian untuk dapat digunakan atau diaplikasikan dalam kegiatan promosi kesehatan.

\section{DAFTAR PUSTAKA}

Bachrun, E., 2017. Hubungan Dukungan Keluarga Dengan Kepatuhan Minum Obat Antiretroviral Pada Orang Dengan HIV/AIDS (ODHA). Jurnal ISSN. (Onine), (http://ejournal.unes.ac.id., diakses tanggal 23 Mei 2018, jam 13.00 WITA).

Dinas Kesehatan Provinsi Bali., 2017. Jumlah Kasus HIV AIDS di Provinsi Bali. Denpasar: Dinkes Prov. Bali.

Depertemen Kesehatan Republik Indonesia., 2008. Pedoman Pelayanan Konseling Dan Tes Testing HIV/AIDS secara Sukarela (Voluntary Conseling And Testing). Jakarta: Durjen P2PL.

Effendi, F. \& Makhfudli., 2009. Keperawatan Kesehatan Komunitas: Teori dan Praktek Dalam Keperawatan. Jakarta: Selemba Medika.

Embi, A. M., 2008. Cabaran Dunia Pekerjaan. Kuala Lumpur: PRIN_ADSDN.

Friedman, Marlyn, M., 2010. Buku Ajar Keperawatan Keluarga Riset, Teori, dan Praktek, Edisi Kedua. Jakarta: EGC.

Harmoko, 2012. Asuhan Keperawatan Keluarga. Yogyakarta: Pustaka Pelajar.

Isni, 2016. Dukungan Keluarga, Dukungan petugas kesehatan, dan Perilaku Ibu HIV dalam pencegahan penularan HIVIAIDS ke Bayi di Jawa Tengah. 
Skripsi tidak dipublikasikan. Fakultas Kesehatan Masyarakat Universitas Ahmad Dalan

Kementrian Kesehatan RI., 2012. Pedoman Nasional Pencegahan Penularan HIV dari Ibu ke Anak. Direktorat Jendral Pengendalian dan Penyehatan Lingkungan. Jakarta: Kemnekes RI.

Jakarta: Kemnekes RI. ., 2016 Penyakit Human Immunodeficienty Virus.

Komisi Penangulangan AIDS Provinsi Bali., 2012. Situasi Kasus HIV/AIDS di Provinsi Bali. Denpasar: Dinkes Prov. Bali.

Mahardining, A. B., 2010. Hubungan Antara Pengetahuan, Motivasi dan Dukungan Keluarga Dengan Kepatuhan Terapi ARV ODHA. Jurnal Kesehatan Masyarakat. 5(2). (Online), (http://journal.unes.ac.id., diakses tanggal 23 Mei 2018, jam 13.00 WITA).

Notoatmojo, 2012. Kesehatan Masyarakat Ilmu Dan Seni. Jakarta: Rineka Cipta. Padila, 2013. Buku Ajar Keperawatan Gerontik. Yogyakarta: Nuha Medika.

Pradnya, D., 2017. Hubungan Dukungan Keluarga Dengan Kepatuhan Program Pengobatan Pasien HIV/AIDS. Skripsi tidak dipublikasikan. STIKes Wira Medika Bali.

Ramayanti, 2011. Hubungan Karakteristik Ibu Hamil Dengan Kejadian Persalinan Prematur. Jurnal Kebidanan. 2(3) (Online), (http://etd.eprints.unnes.ac.id., diakses tanggal 1 Juni 2018, jam 13.00 WITA).

Suprajitno, 2007. Asuhan Keperawatan Keluarga: Aplikasi dalam Praktik. Jakarta: EGC.

Susanto, \& Tantut, 2012. Buku Ajar Keperawatan Keluarga: Aplikasi pada Praktik Asuhan Keperawatan Keluarga. Jakarta: Trans Info Media. 